not question his right to adopt a name; but as I have presumed to apply the term to spurious vaccine, and also to deem his diagnosis incorrect, $\mathrm{I}$ am anxious to reconcile our opinions, and obviate a confusion of pathology.

I believe the form was that of variocella, (or varioloid, so misnamed,) the flat surface of the vesicles distinguishing it from varicella. The vaccination was probably a mere precedent of this modified variola, which may not only be consecutive to, but even synchronous with, vaccine. I believe the patient was saved by the vaccine insertion. In default of this there would have been an unmodified, very severe, and probably fatal variola. I have seen many cases of this clustered or semiconfluent variocella; but, as I have alluded to them in "The Varieties of Pock," I will not intrude further on your valuable columns.

June, 1856

I am, Sir, yours obediently, Walter C. Dendy.

\section{THE ADMINISTRATION OF STRYCHNINE AS} A MEDICINE.

[XOTE FROM DR. FLEETWOOD CHURCHTRX.] To the Elitor of THE LAYCET.

Srr, - Will you kindly allow me space in your journal to correct a mistake which some friends have pointed out in one of my works. At page 86 of my volume on "Diseases of Women," the dose of strychnine is stated to be "from onetenth or one-fourth of a grain to a grain three times a day." I cannot explain how such a mistake occurred; but it is very clear, independent of late revelations as to the power of strych nine, that the latter dose would be a poisonous one. I have always commenced with one-sixteenth of a grain, and increased to' one-twelfth or one-tenth of a grain, and I do not think it would be wise to give much more.

The error having been pointed out to me, I feel that it is my duty to point it out to the profession, and to express my regret.

I have the honour to be your obedient servant, Stephen's-green, Dublin, June, 1856.

F. Churchill.

\section{DR. ASHLEY ON VESICULAR HYDATIDS OF THE UTERUS.}

To the Editor of THE LANCET.

SIR, - As. I have fallen under the "cold shade" of your Reviewer, will you permit me to trespass briefly on your valuable space in reply to his hypercritical remarks.

It is an error to suppose that $I$ have been unmindful of the writings of modern pathologists, and I entertain the conviction that all the more salient points to be educed from their researches have not been overlooked by me. In this view I am supported by the opinion of other reviewers.

Histologists of the present day have proved that the uterine hydatid is a cystic development of the chorion, conjoined with degeneration, and that this membrane is the common seat of hydatic formation. This was clearly indicated by Valisnieri nearly 150 years since.

I have seen attached cysts developed in a nulliparous uterus, and relying on the testimony of Dr. Ashwell, Dr. Hislop, and other accurate observers, I maintain that these growths not only arise on the villi of the chorion, but sometimes, though very rarely, are found in the unimpregnated uterus, probably taking their origin from protein or gelatinous exudations. I remain, Sir, yours faithfully,

Boyne-terrace, June, 1856.

W. H. ASHLEY.

\section{THE PRIVATE COMMITTEE ON LUNACY LAW. To the Editor of THE LANCET.}

Sur,-Would you allow me to inquire through your pages who constituted "the Private Committee on Lunacy Law," and who elected them,-where they reside, and how I can reply to their anonymous circular which was posted yesterday to my country residence, without printer's or secretary's name, or any other means of tracing its author?-an act in itself illegal.

The apparent object of the circular is to agitate against a late order of the Commissioners in Lunacy, requiring lists of the payments made by patients to be kept at the private asy. lums for their inspection. Whether this order be just or legal I am not called upon to determine; a good deal might be said on both sides of the question. But I am called upon and do protest against the underhand way in which the authors of this circular would discuss the question. The authority of the 700
Commissioners in Lunacy must surely be wondrous great, when members of a liberal profession stoop thus to cope with it, under the shade of an anonymous address !

If you would do me the favour of publishing this letter, perhaps one of "the Private Committee on Lunacy" may muster courage to afford me the information I desire.

I am, Sir, your obedient servant,

C. Lockhast Robtnson, M.B. Cantab.

Hon. Sec. to the Association of Medical Officers of Asylums and Hospitals for the Insane.

Charles-street, Berkeley-square, June 16th, 1856 .

\section{"EPILEPSY WITH TETANIC COMPLICATIONS." To the Editor of The LANCET.}

StR,-Lord Campbell, in his summing-up, spealks thus of Dr. Macdonald's evidence: “Dr. Macdonald has gone the length of introducing a new term of disease, 'epilepsy with tetanic complications;" " and a leader of The Times is very severe and sarcastic, and not very courteously applies the term " miserable jargon" to this designation of disease.

Now, the following case from Dr. Aldis' "Introduction to Hospital Practice" perfectly justifies Dr. Macdonald, and proves that "epilepsy with tetanic complications" is not mere hypothesis, but an actual disease. It shows, moreover, how extremely cautious non-professional persons should be before venturing to comment on medical opinions and evidence.

Chelsea ${ }_{4}$ June, 1856 I am, Sir, your obedient servant,

\section{Case of Periodical Opisthatonos.}

"A young man was admitted, on Wednesday, Moy 11th, for fits, accompanied by opisthotonos. On Thursday morning, I saw him labouring under one of his attacks. Mr. Hammerton and Mr. Malton, jun., also were present. The head and feet are drawn backwards, as far as possible, by tetanic spasm. The fit lasted about a quarter of an hour, during which time he was insensible. He gradually recovered, and complained of great pain in the occiput. On examining the head, there ap. peared to be an aperture between the occipital and parietal bones, for on pressing the integuments in that direction, the cerebral pulsation could be felt, as well as the edges of surrounding bone. The boy states that the opening in the skull has existed all his lifetime. The fits recurred frequently; and if he lay on his abdomen during the paroxysm, the head and feet were curved upwards and backwards."

How can the foregoing case be described more accurately than as one of "epilepsy with tetanic complications"?

\section{策arliamentaty 娄ntelligence.}

\section{HOUSE OF COMMONS. Monday, JUne 16 Th.}

MEDICAL RELIEF TO THE POOR.

Sir J. Trollope wished to ask the President of the Poorlaw Board whether he was prepared to adopt the recom. mendations of the Committee of 1854 upon medical relief to the poor, viz: :-1. That medical appointments should be permanent. 2. That the remuneration should be revised and increased. 3. That the districts should be examined.

Mr. Bouverie said, that the recommendation of the select committee, that the area of the medical districts should be examined with a view to their limitation, was being done from time to time as oceasion occurred. The recommendation that the medical appointments should be permanent had been complied with. The third point, that the Poor-law Board should increase the salaries of the medical officers where they were inadequate had been under the consideration of the board, with the view of obtaining a greater remuneration for medical men. That had been done to a certain extent, although not to the fullest extent desirable. An increase of $£ 16,000$ or $£ 17,000$ in the salaries within the last few years had been effected, but it was obvious that, unless a disposition existed on the part of the guardians to concur with the board, it was not possible to do all that was desirable herein.

\section{UNION OF ABERDEEN UNTVERSTTIES.}

Mr. Thompson asked the Lord-Advocate whether he was prepared to bring in a Bill for the union of the Aberdeen Universities? 